\title{
New Record of Psenulus carinifrons iwatai (Hymenoptera: Crabronidae: Pemphredoninae) in Korea
}

\author{
Hyeon Woo Yang and Jeong-Kyu Kim* \\ Department of Biological Sciences, Faculty of Science, Hanseo University, Seosan 356-706, Korea
}

\begin{abstract}
Psenulus carinifrons iwatai (Gussakovskij) is reported for the first time in Korea. This species is defined by its long petiole of sternum I and extensive coloration on legs in both sexes, and simply linear frontal carina in female. Diagnostic description and digital images are presented.
\end{abstract}

Keywords: Psenulus, carinifrons, iwatai, Korea

\section{INTRODUCTION}

The genus Psenulus of the subfamily Pemphredoninae is characterized by the following combination of characteristics: forewing with three submarginal cells; antennal sockets located well above clypeal base; hindwing with media diverging beyond cu-a (Bohart and Menke, 1976). Currently, five species of this genus have been identified in Korea (Tsuneki, 1959, 1974, 1982, 1991; Kim and Yang, 2010).

We have recently found two peculiar specimens identified as Psenulus carinfrons iwatai (Gussakovskij) which was new to Korea. Among the known Far Eastern Psenulus species, this species is easily distinguished by its long petiole of sternum I (much longer than hind femur and almost as long as hind tibia) and extensive coloration especially in legs (fore and mid leg almost entirely bright yellow) in both sexes and simply linear frontal carina in the female.

In the present study, we report this species as a new element of Korean Pemphredoninae fauna. Diagnostic description and digital images are provided.

Morphological terminologies mainly followed those of Bohart and Menke (1976). All measurements were taken as the maximal length of the part being measured under an image analyzer (Tomoro Digital Imaging). Body length was measured from anterior margin of head to posterior end of metasoma. We used three comparative terms to explain puncture distribution: "sparse" (punctures spaced distantly, usually separated from one another by two or three times length of puncture diameter), "moderate" (punctures separated by the puncture diameter), and dense (punctures closely

*To whom correspondence should be addressed

Tel: 82-41-660-1349, Fax: 82-41-688-3403

E-mail: kwasp@hanseo.ac.kr spaced and usually touching one another).

\section{SYSTEMATIC ACCOUNTS}

1*Family Crabronidae Latreille, 1802

${ }^{2 *}$ Subfamily Pemphredoninae Dahlbom, 1835

$3 *$ Tribe Psenini A. Costa, 1858

4*Subtribe Psenina Gittins, 1969

${ }^{5 * G e n u s ~ P s e n u l u s ~ K o h l, ~} 1897$

6*Psenulus carinifrons iwatai (Gusssakovskij)

Psen (Eopsenulus) iwatai Gusssakovskij, 1934: 84-86, 우, Ikeda, Osaka, Japan (Mus. Stockholm).

Psenulus iwatai (Gussakovskij): Tsuneki, 1956: 9 (new combination).

Psenulus carinifrons iwatai (Gusssakovskij): Bohart and Menke, 1976: 172 (new status, listed).

Female. Body length $6.60 \mathrm{~mm}$, and forewing length $4.60 \mathrm{~mm}$. Head. In frontal view, broader than long, $1.28 \mathrm{X}$ as broad as long. Antenna long: antennal scape ca. $1.80 \mathrm{X}$ as long as broad at apex; pedicel almost as long as broad; flagellum I ca. $2.90 \mathrm{X}$ as long as broad at apex; flagellomeres II-III ca. 1.80 to $1.90 \mathrm{X}$ as long as broad at apex; flagellomere IV-XI slightly longer than broad at apex; last segment ca. 1.80 X as long as broad at base. Gena, in profile, ca. $0.85 \mathrm{X}$ as broad as eye in its broadest portion (near mid-level of eye), smooth and shiny, with moderateslanted tiny hairs. Upper two thirds of clypeus with somewhat dense punctures and dense pale yellow appressed hairs, while lower one third almost impunctate and polished with sparse hairs; apicomedinan production short, and its lateral margins somewhat convergent, reversed trapezoid in shape, with apical margin truncate. Apical mar-

${ }^{1 *}$ 은주둥이벌과, ${ }^{2 *}$ 진딧물벌아과, ${ }^{3 *}$ 먹꼬마구멍벌족, ${ }^{4 *}$ 먹꼬마구멍벌아족, ${ }^{5 * ㄲ ㅗ ㄹ ㅣ ㅁ ㅓ ㄱ ㄲ ㅗ ㅁ ㅏ ㄱ ㅜ ㅁ ㅓ ㅇ ㅂ ㅓ ㄹ ㅅ ㅗ ㄱ, ~}{ }^{6 *}$ 호리꼬리먹꼬마구멍벌 (신칭) 


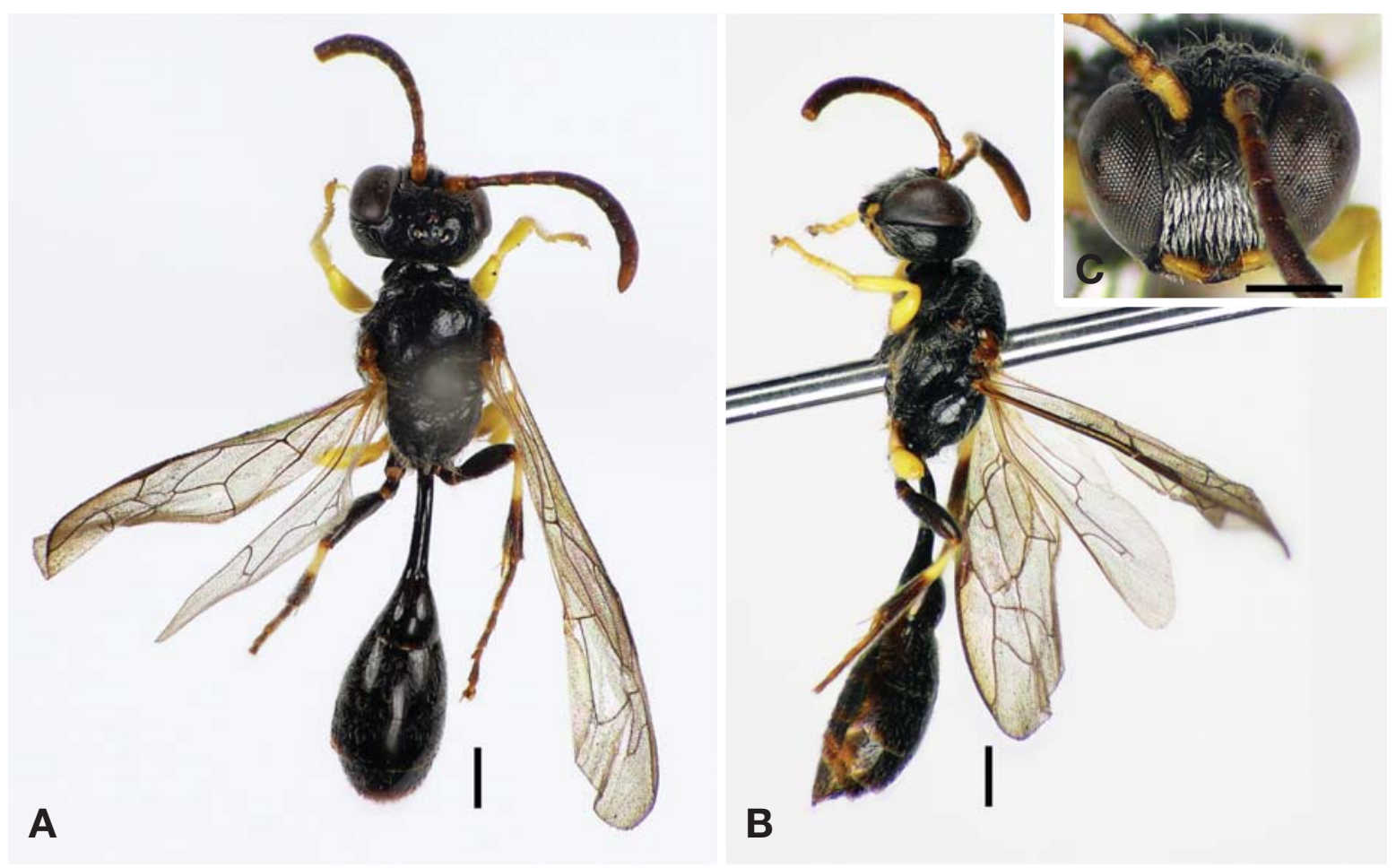

Fig. 1. Psenulus carinifrons iwatai (Gussakovskij), 우. A, General habitus, seen from above; B, General habitus, in profile; C, Head, in frontal. Scale bars: $0.5 \mathrm{~mm}$.

gin of labrum medially notched, and covered with dense, erect, tiny yellow hairs. Supraclypeal area flat with moderate punctures and appressed pale yellow hairs similar to ones in clypeus; frontal carina simply linear from anterior ocellus to clypeal base, without either elliptic plate in interantennal area or lower transverse branching. instead, carina noticeably produced in interantennal area, forming triangular frontal tubercle. Ocellar region and vertex smooth and polished with tiny hairs.

Mesosoma. Anterior sloping face of pronotum with moderate small punctures and slanted tiny hairs; lateral face longitudinally carinate. Mesonotum and scutellum shiny with irregular sparse small punctures. Mesopleuron almost impunctate with sparse, slanted hairs. Mmetapleuron smooth and polished. Propodeal enclosure smooth and polished, with several loose, longitudinal carinae; remaining propodeal dorsum shiny and carinate, with sparse tiny punctures and sparse erect hairs; propodeal lateral face irregularly reticulate, with somewhat dense, long, erect, pale yellow hairs; median groove long triangular in shape in its upper two thirds, and linear in its lower one third, with parallel transverse carinae in its bottom.

Metasoma. Petiole smooth and shiny, without dorsomedian groove, and long (approximately $1.18 \mathrm{X}$ as long as hind femur and almost as long as hind tibiae). Metasomal terga with moderate, tiny punctures and short appressed hairs, without apical hair fringes on sterna IV-V. Pygidial plate wheat-seed like in shape (but bordering carina very faint), and its face weakly shagreened, with irregularly set sparse hairs.

Coloration. Ground color of body black, but labrum, labial and maxillary palpi, glossa, tegula, hind tarsus, lateral margins of terga II-V, and apical margins of sterna III-V brownish to ferrugineous. Mandible except for apical one fourth, antennal scape, lower face of antennal segments II-IV, fore leg, mid leg, and hind coxa, and basal half of hind tibiae bright yellow.

Male. Almost all external features same as in female, except for following details. Body slightly shorter. Antennae much longer, longer than head and mesosoma combined (almost as long as mesosoma in female); flagella I ca. 2.10 as long as broad at apex; flagella II-XI ca. 1.90 to $2.00 \mathrm{X}$ as long as broad at apex; last segment ca. $2.7 \mathrm{X}$ as long as broad at base. Frontal carina branched at its lower end, and each branch reaching lower margin of antennal socket.

Specimen examined. $1 \sigma^{7}$, Incheon, Ganghwa-do, Yeocha-ri, Jun. 1991 (H.J. Lee); 1우, Gyeonggi-do, Yangpyeong-gun, Dogok-ri, 21 Jul. 1998 (Y.B. Lee). 
Distribution. Korea (new record), Japan.

Remarks. Seven subspecies including niminotypical one are currently recognized in Indo-Australian Region widely and the Far East (Bohart and Menke, 1976; Lith, 1978). This subspecies is easily separated from the other subspecies by black (without yellow marking) pronotum, scutellum and metanotum, together with geographical segregation.

\section{ACKNOWLEDGEMENTS}

This work was supported by the Survey of Indigenous Biological Resources of Korea Project, NIBR and the Eco-technopia 21 Project.

\section{REFERENCES}

Bohart, R.M. and A.S. Menke, 1976. Sphecid wasps of the world. California University Press, pp. 1-695.

Gussakovskij, V., 1934. Beitrag zur Kenntnis der Pseninen- und Pemphredoninen-Fauna Japans (Hymen., Sphecidae). Mushi, 7(2): 83-87.

Kim, J.K. and H.W. Yang, 2010. First record of Psen ussuriensis (Hymenoptera: Crabronidae: Pemphredoninae) from
Korea, with a Key and Checklist of current valid species of Korean Pemphredoninae. Korean J. Syst. Zool., 26(2): 141151.

Tsuneki, K., 1956. Taxonomic notes on some species of Pemphredoninae and Crabroninae (Hym., Sphecidae) in Japan. Akitu, 5: 9-12.

Tsuneki, K., 1959. Contributions to the knowledge of the Cleptinae and Pseninae Faunae of Japan and Korea (Hymenoptera, Chrysididae and Sphecidae). Memoirs of the Faculty of Liberal Arts, Fukui University (Series II, Natural Science), 9: 1-78.

Tsuneki, K., 1974. Sphecidae (Hymenoptera) from Korea. Annales Historico-Naturales Musei Nationalis Hungarici, 66: 359-387.

Tsuneki, K., 1982. Sphecidae from North Korea (II) with the list of the species of the family known from the Korean Peninsula (Hymenoptera). Special Publications of the Japan Hymenopterists Association, 20: 1-22.

Tsuneki, K., 1991. Sphecidae (Hymenoptera) from Korea. Insecta Koreana, 2: 198-203.

van Lith, J.P., 1978. Psenini from Sri Lanka (Hymenoptera, Sphecidae, Pemphredoninae). Tijdschriftvoor Entomologie, 121: $1-12$. 